\title{
Towards a Mobile Education of the Sciences of Information in Morocco
}

\author{
doi:10.3991/ijet.v4i1.648 \\ B. Sbihi and S. El jazouli \\ Ecole des sciences de l'Information, Rabat, Morocco
}

\begin{abstract}
This article aims to identify learning needs and continuing learning in information science at the ESI (Ecole des Sciences de l'Information which is the only school in Morocco which purpose is to ensure good training of librarians, archivists and librarians [1]).
\end{abstract}

The first objective is to identify and understand the problems and obstacles faced by students at the school during their system of learning. Then, the present paper aims to identify and analyze the needs of professionals in the context of continuing learning. To achieve the objectives set, we have relied on the method of 'investigation on the ground' as the most research method used for data collection. Besides, in order to make optimal use of new technologies, gain time and reduce the cost, we opted for the use of electronic questionnaire administrated, through the Internet, directly to students and professionals in the Information \& Documentation (I\&D).In addition to the questionnaire, and to deepen understanding of the data collected, ongoing discussions with them have been scheduled.

Finally, to meet the needs already identified, we intend to propose a strategy of learning to implement based on distance learning and teaching mobile.

Index Terms-M-learning, Information science, questionnaire, training needs, Morocco

\section{INTRODUCTION}

The information science constitute an important issue in the era of the knowledge society, this discipline plays a vital role in promoting new jobs such as: knowledge manager, professional of waching or competitive intelligence, record manager, etc. Le Coadic defines 'information science' as "the science that studies the properties of information and process of its construction, its communication and its use" [2].

It builds scientific knowledge, studying phenomena informational and establishes universal relations as well as scientific laws [2].

In Morocco, L'Ecole des Sciences de l'Information (ESI) [1], created since 1974 and which depends on the HCP: Haut commissariat au Plan [3], is the only institution specialized in forming 'informatistes: information specialist' and 'informatistes spécialisés'. These profiles can apply in the management of libraries, archives centers.

Furthermore, and since its creation to 2008, the ESI has formed 2162 managers, from whom 1947 Informatistes and 215 Informatistes Specialisés [4].
They work in ONG, public and private sector and therefore participate in the development of our country. Currently and in order to produce qualified managers, the school should ensure quality training. In order to promote the learning at ESI and to identify the present needs of students and managers of the Information-Documentation I \& D, a national survey on the needs was launched in 2007 [5].

This survey has identified the number of professional of I\&D required in the market and recommended, on the other side, great openness and utilization of technology. In this context, knowledge has become the cornerstone of economic, cultural and social development. The need for training and continuing learning is a huge challenge especially for science, which change continually, such as information science.

In addition to this, technologies of information and communication know an unprecedented evolution that has affected all areas of our lives and especially the information-documentation sector (I \& D). Technological change has affected three major thrusts namely hardware components, software and communications.

Concerning the material terms, the advent of digital cameras, DVD players, mp3, mp4 and still dozens of other devices have given the possibility of multiple uses personal and professional.

In terms of software, the movement of free software and open source provided an opportunity for the third world countries, such as India and China, to take advantage of this development so that for each proprietary software exists its equivalent in the range of free and open source. Concerning the aspect of communication and besides the fact that the Internet is a global public network, the emergence of wireless networks, such as wireless, wimax and 3g, etc. have offered a great convenience and mobility to their users. These new opportunities, which are omnipresent, can be exploited in the learning through electronic, distance and mobile learning. To meet the needs of training and continuing education in Information Sciences, we undertook an investigation on the ground in the needs of both students (from 4 years of the normal cycle and graduate) and frameworks specialized in I \& D. The choice of students from 4 years of the 'cycle normal' as target population stems from the fact that they are on the verge of completing their training and they are regarded as information specialists in contrast to students from lower levels (1st, 2nd and 3rd years of 'cycle normal').

Besides, we found it useful to use mobile technologies which offer many possibilities in the context of distance education to meet the training needs already identified in 
our investigation. It is in this perspective, our paper has as objective to tackle the failures of current education system, and propose solutions through distance education mobile. Finally, through this study, we intend to define the elements of a strategy to set a system of distance learning and mobile at the ESI.

After an introduction, we will present in the second part what we mean by Distance and mobile Learning, and then the third part will be devoted to the presentation of the results of the survey that we conducted. Finally, in the fourth and last part, we expose the elements that we propose for the set of a strategy for a system of distance and mobile learning at ESI, which we consider the best solution.

\section{DistANCE AND MOBILE LEARNING}

The E-learning is a type of education supported by electronic technologies. It's based on the broad dissemination of information across networks and means of telecommunication. It is defined by the American Society for Training \& Development [6] as a use of the Internet and digital technologies in order to create experiences to be used in training.

The European Commission, meanwhile, defined elearning as the use of new multimedia technologies and the Internet to improve the quality of learning by facilitating access to resources, services, trade and distance collaboration [European Commission].

In addition to this, the E-learning helps to foster and facilitate learning, everywhere and at what time the student should be available to attend his courses. It, also, reduces the time and training costs and facilitates the exchange of information with different actors. As well as traditional training, this type of education has actors.

The four actors of e-learning play a great role and participate actively in the learning process and in the knowledge acquisition. The main actors of distance education are the teacher who produced the course, the student who learn, the guardian who is in charge of monitoring and assisting learners and the administrator who takes care of technical problems. In order to make distance learning, a platform such as LMS is used; it's a program that assists the training when the protagonists are geographically dispersed. It is a virtual learning environment which gives help to its users in order to communicate, organize, produce and share ideas or knowledge [7].

In addition to this, the E-learning was widespread and even adopted by the European Union, we give the example of CNED [8], which offers training 3000 to form 350,000 students with 8000 teachers and also the example of the Open University [9] which has 200,000 students registered and 250000 degrees. Furthermore, to add to e-learning the characteristic of mobility, a new mode called M-learning (Mobile learning) has been appeared. The M-learning is a sort of learning through mobile devices and wireless transmission. It is a form of learning that occurs when the learner is not at a fixed location [10]. The M-learning environment makes the Elearning more available and can be regarded as a subdomain of e-learning in which applications include some mobility. It gives the ability to learn anywhere at any time without permanent physical connection to wirenetworks [11].
Driven by the unprecedente movement of technologies if information and communication (TICs) : (MP3 player, MP4, engines of photos and digital cameras, LCD TV, DVD player, Blue ray discs), total number of users of mobile communications networks in the GSM world has just topped three million on April 15, 2008 [12]. While in Morocco, for example, the number of GSM subscribers will increase from 13 million currently to 24 million in 2010 [13]. This evolution promotes the use of $\mathrm{M}$ learning as a tool of learning in the field of information science. The alternatives proposed by mobile devices that allow remote connection such as PDAs, smartphones, or even Iphones PC handheld and tablet PC have emerged as a convenient way through the benefits they offer. Indeed, they are relatively cheap, lightweight and easy to carry and use more intuitive stylus than using the keyboard and mouse. Moreover, with the use of wireless networks and wireless local Metropolitan wimax, access to some Internet users will be easy independently to geographical constraints. With the use of MMS, SMS, voice message or chat on the phone with voice and video, the M-learning will attend a learner on the ground and give him an opportunity to learn not only whenever he wants but where he wants it. What is needed now is correct and pertinent content. Also, we should have registrations and payments in order to take benefits from the use SMS. The mobile devices have limitations that can easily be solved as shown in the following table:

TABLE I.

PROBLEMS OF M-LEARNING AND SUGGESTED SOLUTIONS

\begin{tabular}{|l|l|}
\hline Problems & Solutions suggested able \\
\hline Battery & 2 batteries and battery with sunlight \\
\hline Problem of input & Virtual keyboard \\
\hline Projection & Projection on the wall \\
\hline Memory or storage & Adding memory cards \\
\hline Non permanent connexions & Using Bluetooth or wireless wifi \\
\hline
\end{tabular}

We should keep in mind that the ESI has already launched in 2003 [14] which had as objective the development of the teaching of new information and communication technologies' (ICT) into schools of information science in Africa and who has undergone two sessions the last one was in 2006.

In addition to this, ESI offers distance learning within the FADIS [15] but so far the content for mobile devices has not yet been emerged..

\section{RESULTS OF THE STUDY}

\section{A. Distribution of respondents by number}

Before presenting the results of our investigation, it is important to keep in mind that its objective is to analyze training needs and continuous learning of students and managers at the ESI. This investigation will lead to the proposal for a distance and mobile learning system in order to improve the quality of education provided to professionals in the (I \& D). Our population is composed of 388 people divided up as follows: 
TABLE II.

DISTRIBUTION OF THE POPULATION SURVEYED

\begin{tabular}{|l|l|l|c|}
\hline Type of formation & Population & Number & Total \\
\hline \multirow{5}{*}{ Academic learning } & $\begin{array}{l}\text { 4th year } \\
\text { students of the } \\
\text { normal cycle }\end{array}$ & 82 & \multirow{2}{*}{106} \\
\cline { 2 - 3 } & $\begin{array}{l}\text { 1st year of } \\
\text { graduate 'cycle } \\
\text { supérieur't }\end{array}$ & 12 & \multirow{2}{*}{12} \\
\cline { 2 - 3 } & $\begin{array}{l}\text { 2nd year of } \\
\text { graduate 'cycle } \\
\text { supérieur' }\end{array}$ & 12 & 282 \\
\hline $\begin{array}{l}\text { Continuing } \\
\text { Education }\end{array}$ & upper & 282 & 338 \\
\hline Total & & & \\
\hline
\end{tabular}

Our investigation has targeted a random sample of 59 students of the ESI with a margin error of 5\% [16]. The response rate is $85 \%$ which means 50 respondents that consist of 16 'informatistes' and 34 'informatistes specialisés'. The choice of this method of sample is due to the fact that each individual of the global population has the same probability included in the sample. The 50 respondents were divided into 4 populations each one has fulfilled its own questionnaire; the questionnaire was adapted according to the profile of the respondent. More specifically, the 4 populations are divided according to the cycle of study (normal or higher) and by status (student or staff member). Populations are grouped in the following table:

TABLE III.

IDENTIFICATION OF THE POPULATIONS UNDER STUDY

\begin{tabular}{|c|c|c|}
\hline Cycle & Students & Staff / managers \\
\hline Normal & Population 1 & Population 3 \\
\hline Supérieur & Population 2 & Population 4 \\
\hline Target needs & Academic training & Continuing Education \\
\hline
\end{tabular}

Moreover, the first two populations (populations 1 and 2) will give us an answer on the need for training diploma at the ESI, while the last two populations (populations 3 and 4) we will give an idea the need for continuing education at ESI. Thus, the distribution of 50 investigations as 4 people is presented in the following figure:

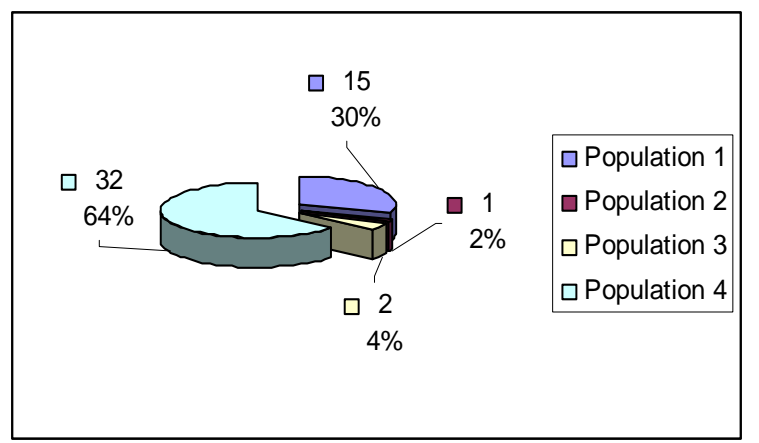

Figure 1. Magnetization as a function of applied field. Note how the caption is centered in the column

The figure above shows that the number of CIS respondents targeted (66\%) is roughly double those of CI (34\%).

\section{B. Distribution of respondents by gender}

At this level, it should be noted that in our investigation, there is not equivalent gender because the male represents $36 \%$ against $64 \%$ for females as shown in the following table:

TABLE IV.

BREAKDOWN OF RESPONDENTS BY GENDER

\begin{tabular}{|c|c|c|c|c|c|c|}
\hline & \multirow{2}{*}{ Profile } & \multicolumn{2}{|c|}{ Male } & \multicolumn{2}{|c|}{ Female } & \multirow{2}{*}{ Total } \\
\hline & & Number & $\%$ & Number & $\%$ & \\
\hline \multirow{2}{*}{ CI } & Population 1 & 3 & 16,67 & 12 & 37,5 & \multirow{5}{*}{$100 \%$} \\
\hline & Population 3 & 0 & 0 & 2 & 6,25 & \\
\hline \multirow{2}{*}{ CIS } & Population 2 & 0 & 0 & 1 & 3,125 & \\
\hline & Population 4 & 15 & 83,33 & 17 & 53,125 & \\
\hline \multicolumn{2}{|c|}{ Total } & 18 & 100 & 32 & 100 & \\
\hline
\end{tabular}

\section{Distribution of respondents by age}

Of the 50 respondents, the average age is 29, 94 years. We found that the youngest respondent has 20 years old while the oldest has 46 years. This interval of age shows that the respondents, which already work, still have time in their careers before reaching the age of retirement which is 60 years.

To that end, we identified the needs of young students and executives who are active, which are relatively young, those that need to upgrade throughout their careers. Thus, the detailed distribution by age is presented in the following table:

TABLE V.

BREAKDOWN OF RESPONDENTS BY AGE GROUP

\begin{tabular}{|l|c|c|c|c|c|c|}
\hline \multicolumn{1}{|c|}{ Age } & $\begin{array}{c}\text { Popu- } \\
\text { lation 1 }\end{array}$ & $\begin{array}{c}\text { Popu- } \\
\text { lation 3 }\end{array}$ & $\begin{array}{c}\text { Popu- } \\
\text { lation 2 }\end{array}$ & $\begin{array}{c}\text { Popu- } \\
\text { lation 4 }\end{array}$ & Total & \% \\
\hline$[$ [8, 23[ & 8 & 0 & 1 & 0 & 9 & 18 \\
\hline$[23,28[$ & 7 & 0 & 0 & 2 & 9 & 18 \\
\hline$[28,33[$ & 0 & 1 & 0 & 15 & 16 & 32 \\
\hline$[33,38[$ & 0 & 1 & 0 & 8 & 9 & 18 \\
\hline$[38,43[$ & 0 & 0 & 0 & 4 & 4 & 8 \\
\hline$[43,46[$ & 0 & 0 & 0 & 3 & 3 & 6 \\
\hline Total & 15 & 1 & 2 & 32 & 50 & 100 \\
\hline
\end{tabular}

\section{Distribution of active respondents by activity sector}

Of the 34 respondents officials, $80 \%$ of them work in the public sector while only $5 \%$ work in the private sector, which show that the public sector constitute the real employer of the ESI's students.

TABLE VI.

DISTRIBUTION OF RESPONDENTS OFFICIALS ON BUSINESS

\begin{tabular}{|c|c|c|c|c|}
\hline \multirow{2}{*}{ Profil } & \multicolumn{2}{|c|}{ Private sector } & \multicolumn{2}{c|}{ Public sector } \\
\cline { 2 - 5 } & $\begin{array}{c}\text { Population } \\
\mathbf{3}\end{array}$ & $\begin{array}{c}\text { Population } \\
\mathbf{4}\end{array}$ & $\begin{array}{c}\text { Population } \\
\mathbf{3}\end{array}$ & $\begin{array}{c}\text { Population } \\
\mathbf{4}\end{array}$ \\
\hline Number & 5 & 0 & 2 & 27 \\
\hline$\%$ & 100 & 0 & 7 & 93 \\
\hline Tsotal & \multicolumn{2}{|c|}{5} & \multicolumn{2}{c|}{29} \\
\hline$\%$ & \multicolumn{2}{|c|}{15} & \multicolumn{2}{|c|}{} \\
\hline
\end{tabular}




\section{E. Distribution of respondents by means of internet access $s$}

All respondents to our survey have access to the Internet. This result is quite encouraging for the technic of m-Learning, so distance learning and mobile can play an important role in shaping them.

It is necessary to clarify that even if all respondents have access to the Internet, means of access differs. At this level, it is important to note that access to the Internet from home occupies the first place (70\%), followed by access via the laboratories of the school (44\%, this mean is also used by students of 'cycle normal' as those in 'cycle supérieur') and then connect to the office (18\%) of respondents who already exercise. Regarding the frequency of Internet connection, over $80 \%$ of respondents are connected to the Internet several times a day which proves that the Internet is a good way of training and a vital source to be continually.

On the other hand, $50 \%$ of our populations are satisfied by the flow, while only $15 \%$ say that they are not satisfied. The flow is a vital factor in navigation and search on the Internet but with the evolution of technologies, the trend tend to bring all the users of internet satisfied by the flow.

It remains to point out that the omnipresence of our sample, $80 \%$, on the net is justified by the fact that they use the Internet primarily for purposes of research and mailing, and at this level, we can deduce that the omnipresence of this large percentage of people will help learners to undergo training at a distance, exchange ideas, discuss with teachers and tutors.

\section{F. Degree of satisfaction of the existing system of education $s$}

$8 \%$ of respondents are very satisfied with the current training, $40 \%$ are satisfied, $28 \%$ are moderately satisfied and only $8 \%$ are dissatisfied with the current education system. The following figure illustrates the appreciation of respondents of the current system of education:

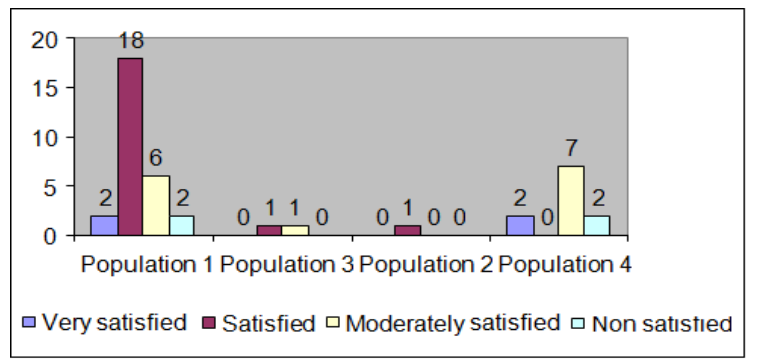

Figure 2. Distribution of respondents depending on the degree of satisfaction

Generally, training in the ESI is satisfactory but the respondents prefer that their training be completed by additional courses and discussion forums in order to resolve some problems when carrying out their homework.

The non availability, especially officials who have administrative constraints, is a major problem for monitoring the traditional training. Thus, we believe that distance and mobile learning will help to develop the knowledge of the professional of I\&D.

\section{G. Technological means available to respondents $s$}

$71 \%$ of respondents have a laptop, $40 \%$ have bought it during the last year, which indicates that the material is relatively recent and powerful and only $7 \%$ have it since more than 5 years. The possession of such material would promote the use of e-learning to complete the academic and continuous training.

It remains to point out that $8 \%$ of respondents $(50 \%$ population 4 , $25 \%$ of population 1 and $50 \%$ population 3 ) say they have equipment other than a laptop or regular access to the Internet; they have access to internet by Pocket PC or mobile phone.

Regarding mobile phones, all members of our population has one, but only one respondent does not have one, considering it a violation of privacy. We can also notice that $90 \%$ of respondents said they had a mobile phone for more than 5 years. So, the data collected shows that education through mobile phone is possible.

\section{H. Technological means of respondents}

More than $90 \%$ of respondents, who said they have already heard m-Learning, are either satisfied or moderately satisfied with the way training m-Learning. In addition, $90 \%$ of respondents expressed the wish to participate in training sessions of m-Learning in the field of information science. Besides, respondents prioritized the reasons why they wish to attend sessions in mLearning:

- Ability to learn at whatever time and space;

- Cultivate self-reflection;

- Offers interactivity;

- Reduces training costs

Moreover, $10 \%$ of respondents who expressed their refusal to participate in training sessions of m-Learning in information science justify it by the following reasons:

- Requires mastering of ICT;

- Scarcity of bids;

- Requires training tutors and professors.

$70 \%$ of respondents want to follow the training mLearning using the two modes (présentielle and distance) and $64 \%$ of respondents want to follow all the curricula by the technic of m-Learning.

Taking into consideration these results, we can propose key elements of a strategy to ensure coeducation (en présentielle and distance) with either the web or with mobile devices to meet the needs in terms of training for students and managers of the ESI .

\section{StRategy OF Mobile TeAching}

The education is extremely important aspect for the cultural, social and financial development of our country. It must be conducted in a thoughtful and correct manner and by using optimally the allocated resources.

Our study has shown that there is a significant need in regard to the training and continuing education. We then propose to tackle this problem, the implementation of a system of distance and mobile learning which includes two types of training. The first training, specific to students from both cycles and the second one relative to the staff as form of continuing education. Similarly, it proposes a strategy for the medium term ( 4 years), this 
strategy will be based on the results of the investigation already undertaken to provide qualitative training at the ESI. We should keep in mind that distance education is emerging as convenient and cheaper to make academic training or continuing education diploma certifying. It is important to remember that our mission is to promote, develop the teaching of information science while using ICTs.

Our strategy is articulated around three objectives:

- Promote the education sector, mainly the one of information science;

- Create a mixed space for training;

- Enhance and motivate the use of ICTs in education.

For these objectives, we proposed three steps to implement our strategy which are illustrated in the figure below:

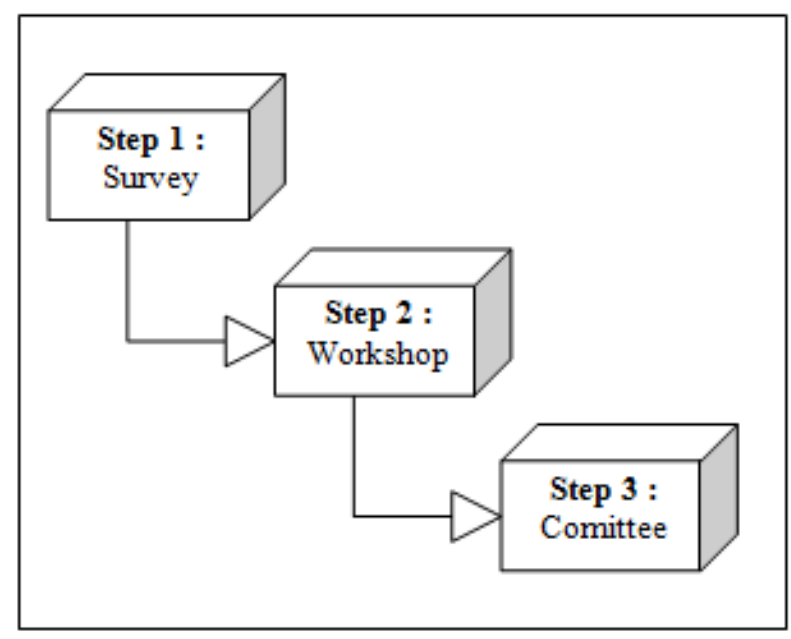

Figure 3. Steps strategy

As illustrated above, our strategy consists of three stages:

- Firstly, we conducted a survey on the Internet to identify and analyze the learning needs. This step is already crossed through the results presented in this paper;

- secondly, we propose to hold workshops free expression uniting all the actors from school: teachers, students, etc;

- finally, it is the constitution of a committee composed of refresher training actors, they should meet daily to propose a strategy and ensure its good implementation.

Our reflexion is composed by three components:

- A report on the phases, stages and the results obtained;

- The draft medium-term strategy;

- The plan of action to implement this strategy.

The results of the investigation have shown that students have the technological means to use or do distance learning.

They are so motivated and therefore we propose to train, assist and granting them diplomas, but always with distance education as a complement to the training unlike FORCIIR project which proposed training certification $100 \%$ distance.
At this level, it is important to note that the strategy, we propose, is characterized by the fact that it relies on the technique of mobile learning.

In fact, the courses will be saved as audio and video files, in addition to text and images, in the form of PDF files to allow broad dissemination on pc, ipod, iphone, Mobile and others. To do so, each room or 'amphi' must be equipped with a digital camera connected to the server allowing the display of course live in synchronous mode, it through videoconferencing. The courses will also be available asynchronously, useful tool in case where the learner is not available during the course of the synchronous mode.

The asynchronous mode offers the opportunity to read the course several times on a mobile platform at a distance.

Pointing out at this level that an inscription and a payment shall be required in this case to limit the number of connections to the server, on the one hand, and to have a small budget for maintenance and improvement of training, on the other side. In addition to this, the courses will be captured by a digital camera and made available to students on the site, copies on DVD, CD may be sold by the hotel.

We also plan to create a Web TV school, at long term, if the training is widespread at the national and international level. The advantage of this technique is that it will allow students to attend courses in their rhythms and overcome the temporary and geographical constraints. Besides, some courses can be podcasting (podcast), which is a free distribution of audio or video files with a subscription to the RSS or Atom.

Remembering at this level that the educational program of online training will be additional and complementary to the training en présentielle in order to improve the quality of learning. Indeed, If a student is blocked, he may use the forum of discussions or chat, SMS, MMS or online chat to discuss issues relating to courses, to do QCM, to make personal work at home. In addition to this, agreements with Moroccan telephone operators must be studied in order to take benefit of forfeits when using SMS and MMS.

In order to present the necessary means for the implementation of this system, we designed a table to resume the key elements of our strategy, designed to medium term and that includes the following points: 
TABLE VII.

ELEMENTS OF THE STRATEGY

\begin{tabular}{|c|c|c|}
\hline \multicolumn{2}{|c|}{ Aspects } & Proposal \\
\hline \multirow{4}{*}{ Means } & Human & $\begin{array}{l}\text { Teachers of the school and inviting other } \\
\text { ones. } \\
\text { Specialised staff on computer }\end{array}$ \\
\hline & Material & $\begin{array}{l}\text { PCs Pocket, mobile phone and Gsm for } \\
\text { students; } \\
\text { Teachers has already their PCs to develop } \\
\text { and conceive a good content } \\
\text { Server to host platform }\end{array}$ \\
\hline & Software & $\begin{array}{l}\text { Lunix as free operating system } \\
\text { Apache et Mysql as server of databases } \\
\text { Moodle as the best platform opensource } \\
{[17],[18]}\end{array}$ \\
\hline & Financial & $\begin{array}{l}\text { Revenues of distant learning of the managers } \\
\text { implicated in continuing education }\end{array}$ \\
\hline \multicolumn{2}{|c|}{ Approach } & $\begin{array}{l}\text { Bottum- up approach } \\
\text { Each teacher will bring the content of his } \\
\text { online course on the platform } \\
\text { Evaluations will be en présentielle at the } \\
\text { school }\end{array}$ \\
\hline \multicolumn{2}{|c|}{ structures } & $\begin{array}{l}\text { a structure in the form of department. } \\
\text { Each department head will play the role of a } \\
\text { tutor in a specific area. } \\
\text { The teachers play the role of teachers in } \\
\text { présentielle and distance by putting content } \\
\text { online. }\end{array}$ \\
\hline \multicolumn{2}{|l|}{ content } & $\begin{array}{l}\text { Platform to develop training courses, } \\
\text { supplements of courses, areas of discussions, } \\
\text { useful links. The design of the platform may } \\
\text { even be a project of study. } \\
\text { The platform has to ensure a certain } \\
\text { coherence / relevance of the content. } \\
\text { At this level, it is also imperative to specify } \\
\text { access rights, passwords, connection rules }\end{array}$ \\
\hline \multicolumn{2}{|c|}{$\begin{array}{l}\text { Accompanying } \\
\text { measures }\end{array}$} & $\begin{array}{l}\text { Institutionalize the mixed mode training } \\
\text { Ensure the conscience and the awareness of } \\
\text { teachers and students about the benefits they } \\
\text { can take advantage of mixed learning and } \\
\text { especially distance learning. } \\
\text { Training on the use of equipment dedicated } \\
\text { to training } \\
\text { Continuous assessment of training } \\
\text { Communication Plan: brochures, flash news } \\
\text { on the web site, etc. }\end{array}$ \\
\hline
\end{tabular}

Finally, we should note that this proposal is based on simple means and at less cost and rely on open source software and revenue of managers in order to cover the cost of this new mode of learning.

\section{CONCLUSION}

The strategy's elements outlined in this article are based on an electronic survey which, despite its shortcomings and weaknesses, has tried to provide more information about the current state of training in the ESI, since it focused on the need for basic training and continuous one in the ESI.

In addition to this, the survey highlighted various claims of respondents and by $t$ he way raised the major problems that hinder the successful pursuit of their academic learning.

Thus, while using the new opportunities offered by the technology constantly evolving, we proposed elements of a strategy of setting up a distance and mobile system of learning. The distance system of learning proposed will ensure the academic training and then the continuous one throughout the life of 'informatistes' and 'informatistes spécialisés' in order to be continually up to date. At the end of this article and after having dressed the list of the key elements of our strategy, it would be useful to reflect intelligently on other aspects namely the integration of reform, the creation of specialized masters and doctoral cycles and recruitment of specialized professors. Stakeholders in the domain of education and training must also seize the opportunities and profits at the age of the knowledge society to promote the education system in Morocco.

\section{REFERENCES}

[1] ESI : Web Site of the School of Information Science. [Available on line], [consulted on: 08-04-08]. Available at :www.esi.ac.ma

[2] [Le Coadic, Y-F (2005). How information science is a part of science? [Available on line], [consulted on: 08-04-08]. Available at

http://prisma.cetac.up.pt/artigospdf/4_quest_ce_qui_fait_science_ dans science de linformation_yves francois_le_coadic.pdf

[3] High Comissioner of Plan. [Available on line], [consulted on: 0804-08]. Available at :www.hcp.ma

[4] ESI. Guide of the School of Information Science. [Available on line], [consulted on: 08-04-08]. Available at : http://www.esi.ac.ma/webesi/guide.pdf

[5] ESI : Web Site of the School of Information Science. Survey on the needs 2007. Survey of the needs of Morocco in term of professional of I\&D Information - Documentation : report . [Available on line], [consulted on: 08-04-08]. Available at : http://www.esi.ac.ma/webesi/SyntheseRapport.doc

[6] American Society for Training \& Development. [Available on line], [consulted on: 08-04-08]. Available at http:/www.astd.org

[7] Boudyach, H. Platforms of e-learning. [Available on line], [consulted on: 08-04-08]. Available at :http://www.elkharki.africaweb.org/distant/montada/boudyach.pdf

[8] CNED. [Available on line], [consulted on: 08-04-08]. Available at: http://www.cned.fr

[9] Open University http://www.open.ac.uk

[10] Malley. cited in the course of Bertrand DAVID, [Available on line], [consulted on: 08-04-08]. Available at : www.lirmm.fr/eiah2006/cours/cours3.3.pdf

[11] Georgiev, T ; Georgieva, E ; Smrikarov, A. M-Learning - a New Stage of Å-Learning. [Available on line], [consulted on: 08-0408]. Available http://ecet.ecs.ru.acad.bg/cst04/Docs/sIV/428.pdf.

[12] Journal of the net. [Available on line], [consulted on: 08-04-08]. Available at http:/www.journaldunet.com/breve/25837/plus-de-3milliards-de-personnes-sont-abonnees-au-gsm.shtml

[13] FBF. 24 millions of GSM users in Morocco in 2010. [Available on line], [consulted on: 08-04-08]. Available at : www.webmanagercenter.com/management/article.php?id=23922

[14] ESI : Web site of the School of Information Science. FORCIIR's project. [Available on line], [consulted on: 08-04-08]. Available at : http://www.esi.ac.ma/forciir/

[15] ESI : Web Site of the School of Information Science. FADIS. [Available on line], [consulted on: 08-04-08]. Available at : http://www.esi.ac.ma/FADIS/site FADIS-eSI/catalog.htm

[16] Alalouf, S. Determining the size of a sample. [Available on line], [consulted on: 08-04-08]. Available at : http://prevert.upmfgrenoble.fr/ alatour/enseignement/SOND/Documents/docalalouf/ Chap3.pdf

[17] Saint-Venant, L. Evaluation of learning Platform for UM2. [Available on line], [consulted on: 08-04-08]. Available at : http://www.refer.ga/IMG/pdf/Etude_comparative.pdf

[18] Graf, S ; List, B. An Evaluation of Open Source E-Learning Platforms Stressing Adaptation Issues. [Disponible en ligne], [Available on line], [consulted on: 08-04-08]. Available at : http://moodle.org/other/icalt2005.pdf 
[19] Alexander, B. "Going nomadic: Mobile learning in higher education”, In . EDUCAUSE Review. Vol39, p285, 2004

[20] Attewell, J., \& Savill-Smith, C. Learning with mobile devices: A book of papers. London, UK, Learning and Skills Development Agency, 2004

[21] Chang, C.-Y., Sheu, J.-P., and Chan, T.W. "Concept and design of Ad Hoc and Mobile classrooms." In. Journal of Computer Assisted Learning 19(3): 336-346, 2003, doi:10.1046/j.02664909.00035.x

[22] European Commission. [Available on line], [consulted on: 08-0408]. Available at : http://ec.europa.eu/

[23] [Jonassen 1995] : Jonassen, D.H. "Supporting communities of learners with technology: a vision for integrating technology with learning in schools”. In. Educational Technology, vol 35 (4), pp. 60-63, 1995

[24] Lewandowski . New way of learning : e-learning : issue and tools. Jean-Claude Lewandowski, Editions of Organisation. 2003

[25] Livingtston, Alan. "Smartphones and other mobile devices: The Swiss Army knives of the 21st century”. In , EDUCAUSE Quartely, Vol 2, pp. 46-52, 2004

[26] McConnetha, D. Mobile Learning in the Classroom. Research paper on the use and effectiveness of using mobile phones for learning with college students using a commercial m-learning platform. West Chester University [Delivered at SALT Conference in Arlington, 2007]
[27] G.Rumble , Management of system of e-learning, Paris : UNESCO, IIPE, 2003

[28] Quinn, C. (2002). "Flexible Learning: Mobile Learning Objects." Retrieved 11/06/03, from http://www.ottersurf.com/MLO-WP.pdf

[29] Sanregret, B, Mobile eLearning: A Reality. Created with University of Georgia and Hot Lava Software. Washington DC : Society for Applied Learning and Technology Conference Orlando, 2007

[30] Taylor, J., Sharples, M., and O'Malley, C., Vavoula, G, and Waycott, J. "'Towards A Task Model for Mobile Learning: A Dialectical Approach', to appear in the Int”, In Journal of Learning Technology, Vol. 2, No. 2, in press

\section{AUTHORS}

B.Sbihi is with the Ecole des Sciences de l'Information BP 6204-Agdal Rabat, MOROCCO (mail: Bsbihi@esi.ac.ma)

S.El jazouli is with the Ecole des Sciences de l'Information BP 6204-Agdal Rabat, MOROCCO (mail: Sihamjazouli@yahoo.fr)

Manuscript received 15 August 2008. Published as submitted by the authors. 